FTAMP 16.21 .45

\title{
Мухамедсадыкова А.Ж.
}

Ph.D докторанты, Сямынь Университеті, ҚХР Сямынь қ., e-mail:860258344@qq.com

\section{ҚЫТАЙ ЖӘНЕ ҚАЗАҚ ТІААЕРІНІН ТУЫСТЫҚ ATAУ СӨЗАЕРІНІН СӨЗЖАСАМ ЕРЕКШЕАIKTEPI}

Бұл мақаланың мақсаты - қытай және қазақ тілдерінің туыстық атау сөздерінің сөзжасам жүйесін сипаттап, олардың ерекшеліктерін мен ұқсастықтарын айқындау.

Зерттеу әдіснамасы - ғылыми зерттеу барысында, тіл білімінің, оның ішінде салыстырмалы тіл білімінің негізгі принциптері: сипаттамалық және салыстырмалы әдістер негізге алынды. Сонымен қатар, құрылымдық әдіс те қолданылды.

Мақаланың өзектілігі - қытай және қазақ тілдерінің туыстық атау сөздерінің синтетикалық, және аналитикалық сөзжасам жүйесі, олардың ерекшеліктері.

Бұл мақалада қытай және қазақ тілдерінің туыстық қарым-қатынасты білдіретін, рухани лексиканың бір тобына жататын туыстық атаулар сөздерінің сөзжасамы зерттеледі. Жалпы туысқандық қатынастар жүйесі қандай да болмасын халықтың рухани, мәдени өмір сүру салтымен тікелей байланысты қалыптасып, құндылықтар жүйесін құрайды. Туыстық атаулардың зерттелуі осыдан бір ғасыр бұрын басталып, әр түрлі тілдер мен халықтардың тарихи-этнографиялық, еңбектердің объектісі болып отыр. Туыстық атаулардың сан ғасырық тарихы, жүйелі құрылымы, мәдениетаралық коммуникация үшін аса маңызды ерекшелігі бар. Қазақ тілі түркі тілдерінің ішінде туыстық атауларға ең бай тіл ретінде аталса, қытай тілі дүниежүзіндегі тілдер ішінде туыстық атауларға бай тіл ретінде қарастырылады. Сол себептен де, ұсынылып отырған ғылыми мақала қытай және қазақ тілдерінің туыстық атау сөздерін мингвистикалық тұрғыдан, оның ішінде тіл білімінің салыстырмалы әдісін пайдалана отырып, сөзжасам ерекшеліктерін зерттейді. Қытай және қазақ тілдерінің туыстық атауларының сөзжасам ерекшелігі бұрын-соңды зерттелмеген тақырып болғандықтан, қытайтану саласында өзіндік орнын табатын өзекті мәселенің бірі болып табылады.

Түйін сөздер: қытай тілі, қазақ тілі, туысты атау, сөзжасам, салыстырмалы зерттеу.

Mukhamedsadykova A.Z.

Ph.D. student of Xiamen University, China, Xiamen, e-mail:860258344@qq.com

\section{Peculiarities of Word Formation of Kinship Terminology in the Chinese and Kazakh Languages}

The purpose of this article is to describe and identify the peculiarities of word formation of kinship terms in the Chinese and Kazakh languages.

Research methodology - this scientific study used the basic methods of comparative linguistics, including descriptive, apostolically, as well as structural method.

The relevance of the article is the system of word formation of terms of kinship in the Chinese and Kazakh languages, similarities and differences of this system.

This article is devoted to the peculiarities of word formation of kinship terms in the Chinese and Kazakh languages. Kinship is a social concept, moreover, a historical-ethnic one, since its development is conditioned not only by universal laws, but also by the way of life, culture, and morality of this or that ethno-collective. But the terms of kinship - these are the words that denote the family relationships between people. They are not only part of the vocabulary of the language, but also the spiritual vocabulary of each language. After all, regardless of the difference between languages and a nation, family ties were always the property of society. Kinship terms are distinguished by their rich history, systemic structure, and also an indispensable role in intercultural communication. Among the Turkic languages, the Kazakh language is considered one of the richest in terms of the number of kinship terms. Chinese is one of the 
richest languages in the world in terms of kinship terms. This scientific article by the method of concurrent analysis studies the peculiarities of the word formation of kinship terms in the Chinese and Kazakh languages. Previously, the formation of kinship terms in these languages has not been studied, which in turn indicates the relevance of this topic in the field of Sinology.

Key words: Chinese language, Kazakh language, Kinship terms, Word formation, Contrasting analysis.

\author{
Мухамедсадыкова А.Ж. \\ Ph.D. Аокторант, Сямыньского Университета, Китай, г. Сямынь, \\ e-mail: 860258344@qq.com
}

\title{
Особенности словообразования терминов родства в китайском и казахском языках
}

Целью данной статьи является описание, а также выявление особенностей словообразования терминов родства в китайском и казахском языках.

Методология исследования - в данном научном исследовании использовались основные методы сравнительного языкознания, в том числе описательный, сопоставительный, а также структурный методы.

Актуальность статьи - система словообразования терминов родства в китайском и казахском языках, сходства и различия данной системы.

Аанная статья посвящена особенностям словообразования терминов родства в китайском и казахском языках. Родство - это понятие социальное, более того, историко-этническое, так как его развитие обусловлено не только всеобщими закономерностями, но и бытом, культурой, моралью того или иного этнокоммектива. А вот термины родства - это такие слова, которые обозначают родственные отношения между ^юдьми. Они являются не только частью словарного состава языка, а также духовной мексикой каждого языка. Ведь независимо от разности языков и нации семейные узы были всегАа достоянием общества. Термины родства отличаются своей богатой историей, системным строением, а также незаменимой ролью в межкультурной коммуникации. Среди тюркских языков казахский язык считается одним из самых богатых по количеству терминов родства. Китайский язык является одним из самых богатых языков мира по количеству терминов родства. Аанная научная статья методом сопоставительного анализа изучает особенности словообразования терминов родства в китайском и казахском языках. Ранее словообразование терминов родства в данных языках не было изучено, что в свою очередь говорит об актуальности данной темы в сфере китаеведения.

Кмючевые слова: китайский язык, казахский язык, термины родства, словообразование, сопоставительный анализ.

\section{Kipicne}

Кез келген халықтың өзіндік, қайталанбайтын, ұлттық ерекшеліктерін, өзіне тән өзгешеліктерін құрайтын әдет-ғұрып лексикасы бар. Туыстық атаулар дәл осы ерекше сөздер қатарына кіреді. Себебі бұл сөздердің қалыптасуы мен дамуы бергілі-бір этностың өмірімен, тұрмыс-тіршілігімен, мәдениетімен, әдет-ғұрып, салт-санасымен тығыз байланысты. Яғни әр халықтың туыстық атауларын зерттеу арқылы көптеген тарихи-этнографиялық сұрақтарға жауап алуға болады. Ал енді бірнеше тілдің туыстық атауларын салыстыра зерттеу нәтижесінде, сол тілде сөйлейтін халықтардың тілі мен мәдениетінің ұқсастықтары мен айырмашылықтарын айқындауға болады. Қалай болғанда да қытай және қазақ халқы сонау ерте заманнан бері келе жатқан көршілес халықтар. Екі ел арасындағы қарым-қатынас тек қана экономикалық салаға шектеліп қойған жоқ, тіл мен әдебиет, мәдениетке де әсерін тигізді.
Қытай тілінің туыстық атаулар жүйесі дүниежүзіндегі тілдердің ішінде ең күрделі жүйенің бірі болып табылады. Сонау ерте заманнан бері қалыптасқан бұл жүйе уақыт өте өзгерістерге ұшыраса да, өз ерекшеліктерін жойған жоқ.

Қазақ тілінің туыстық атаулары түркі тілдес тілдердің ішінде ең байы болып есептеледі. (Диуанова.Р.К. 2010: 3) Аталған тілдердің туыстық жүйесін жеке дара, тарихи-этнографиялық тұрғыдан зерттеген еңбектердің саны өте көп. Алайда қытай және қазақ тілінің туыстық атауларын, әсіресе олардың сөзжасамын ерекшеліктерін салыстыра зерттеген еңбектер жоқтың қасы. Сөзжасам дегеніміз - кез келген тілдегі жаңа мағыналы туынды сөздердің қалыптасуы мен мағыналық дамуын, жасалу тәсілдерін зерттейтін тіл білімінің саласы. (Қазіргі қазақ тілінің сөзжасам жүйесі. 1989). Яғни қытай және қазақ тілінің туыстық атауларының сөзжасамын зерттеу арқылы, біз бұл ұғымдардың жасалуы, қалыптасуы, жасалу сипаты мен әдіс-тәсілдерін, 
ішкі құрылымын тереңірек түсінуге мүмкіндік аламыз. Ал бұл зерттеліп отырған тақырыптың өзектілігін арттыра түсетіні сөзсіз.

\section{Материалдар мен зерттеу әдістері}

Зерттеу жұмысына қатысты негізгі материалдар бұл қытай және қазақ тілдерінің сөздіктері. Қытай тіліне қатысты сөздіктер:

王火、王学元的《汉语称谓词典》（辽宁大 学出版社, 1988年)、

鲍海涛、王安节的《亲属称呼词典》（吉林 教育出版社, 1988年)、

陆瑛的《简明称谓辞典》（广西民族出版 社, 1989年)、

《现代汉语词典》第七版, （商务印书 馆）2016年。

Қазақ тіліне қатысты сөздіктер:

Қазақ тілінің түсіндірме сөздігі. - Алматы, 1974-1986 ж.

Қазақ тілінің түсіндірме сөздігі. - Алматы, 2008 ж.

Ғылыми жұмысты жазуда отандық және шетелдік ғалымдардың іргелі теориялық пікірлеpi мен тұжырымдары қолданыс тапты. Әсіресе қытай тілінің сөзжасамын зерттеу барысында 冯汉瀷мырзаның 1989 жылы жарық көрген 《 中国亲属称谓指南》 еңбегіне жүгінуге тура келді. Себебі бұл еңбек туыстық атаулардың сөзжасамын алғашқы болып, жік-жігімен зерттеуді ұсынды, сонымен қатар әлі күнге дейін қытайтанушы ғалымдардың назарында. Қазақ тілінің туыстық атауларына қатысты мәліметтерді М. Сарыбаева «Система обозначении родства в английском, русском и казахском языках», Л. Жолдасбек «Қазақ сөйленістеріндегі туыстық атаулар», Р. Диуанова «Қазақ тіліндегі туыстық атаулардың мағыналық құрылымы мен лексикографиялану ерекшеліктері» еңбектеріне сүйенуге тура келді. Алайда бұл ғылыми еңбектер қазақ тілінің туыстық атауларының нақты сөзжасам мәселесін қысқаша ғана шолу ретінде тоқталған. Сол себептен де автор жалпы қазақ тілінің сөзжасам ережелеріне сүйене отырып, қазақ тілінің туыстық атауларының сөзжасам ерекшеліктерін айқындады.

Ғылыми-зерттеудегі жалпы тіл білімінің сипаттамалық және салғастырмалық әдістерін пайдаланды. Яғни қытай және қазақ тілдерінің туыстық атауларының сөзжасамына толықтай сипаттама беріліп, олардың жасалу жолдары көрсетілді. Осының нәтижесінде тілдердің сөзжасамына салыстыру жасалды.

\section{Талқылаулар мен нәтижелер}

Қытай тіліндегі туыстық атау терминдерінің сөзжасам ерекшеліктері

Қытай тілінің туыстық атау жүйесі өте толық, сан алуан, дүниежүзіндегі тілдер арасында туыстық атау жүйесі ең күрделі жүйенің бірі болып табылады. 冯汉䩀 мырза өзінің 《中国亲属称谓 指南》атты еңбегінде, қытай тілінің туыстық атау терминдерінің сөзжасамының төрт түрін ажыратты. Олар: 核心亲属称谓 (түбір сөздер), 基本修饰语(айшықтау тәсілі), 重叠 (қайталама тәсілі), 附加词 (қосымша жалғау тәсілі). (冯汉 䩀. 1989). Әрбір тәсілге жеке тоқталып кетуді жөн көріп отырмыз.

Түбір сөзден жасалған туыстық атаулар

Түбір сөзден жасалған туыстық атаулардың түбірі туыстық қатынасты білдіретін негізгі морфемадан тұрады. Бұл морфемалар жеке дара сөз болып, негізгі бір немесе бірнеше мағынаны білдіруі мүмкін. Мысалы: “姑 父”、“姨夫”、“舅父”、“舅妈”、“孙子”、“孙 女”және т.б.

冯汉骥мырза 《中国亲属称谓语指南》еңбегінде негізгі морфемадан құралған 23 сөзді атаса, кейіннен阮氏翠幸 өзінің 《汉、越语亲属称谓语 对比研究》атты докторлық диссертациясында “婶”морфемасын жалғап, барлығы 24 сөз: 祖、 岳、夫、伯、母、姑、叔、姨、婶、舅、兄、 弟、姐、妹、夫、妻、嫂、媳、女、子、婿、 侄、甥、孙。Оның ішінде祖、夫、伯、叔、 舅、兄、弟、夫、子、婿、侄、甥、孙13 c 13 ер жынысына қатысты болса, 母、姑、姨、婶、 姐、妹、妻、嫂、媳、女 10 сөз әйел жынысын білдірсе, 岳 сөзі ер және әйел жынысына қатысты қолданылады. Аталған сөздердің туыстық қатынастық түріне қарай ажырататын болсақ, 7-yі - некелік қатынасты білдіріп (岳、夫、 妻、婿、婶、嫂、媳), 14 сөз қандық туыстық қатынасты білдіреді. Сонымен қатар, 9 сөз тікелей қандас туыстықты білдірсе, 15 сөз жанама және некелік қатынасты білдіреді ( 阮氏翠幸. 2016: 50). Қытай тілінің туыстық атауларын білдіретін негізгі түбір морфемалар Қытайдың патриархалдық жүйесін, ұл баланы қадірлеп, қыз балыны кемсіту идеологиясымен қатар, туыстықтың алыс және жақын түрін ажыратады. Аталған ерекшеліктерді төменде көрсетілген 1-кестеде байқауға болады. 
Қытай және қазақ тілдерінің туыстық атау сөздерінің сөзжасам ерекшеліктері

1-кесте. Қытай тілінің туыстық атауларын білдіретін негізгі түбір морфемалар

\begin{tabular}{|c|c|c|c|c|c|c|c|c|c|}
\hline & \multirow{2}{*}{$\begin{array}{l}\text { Мор- } \\
\text { фема }\end{array}$} & \multirow{2}{*}{ Түсіндірмесі } & \multicolumn{2}{|c|}{ Жынысы } & \multirow{2}{*}{$\begin{array}{c}\Theta_{3} \\
\text { жұрт }\end{array}$} & \multirow{2}{*}{ Нағашы } & \multirow{2}{*}{ Некелік } & \multicolumn{2}{|c|}{ Туыстық түрі } \\
\hline & & & Ep & Әйел & & & & Жақын & Алыс \\
\hline 1 & 祖 & Әкенің әкесі & + & - & + & - & - & + & - \\
\hline 2 & 岳 & Әйеліңнің әке-шешесі & & + & - & - & + & - & + \\
\hline 3 & 父 & Өз әкең & + & - & + & - & - & + & - \\
\hline 4 & 伯 & Әкеңнің туған ағасы & + & - & + & - & - & + & - \\
\hline 5 & 母 & Өз анаң & - & + & - & + & - & - & + \\
\hline 6 & 姑 & $\begin{array}{c}\text { Әкеңнің туған апай, } \\
\text { қарындастары }\end{array}$ & - & + & + & - & - & - & + \\
\hline 7 & 叔 & Әкеңнің туған інісі & + & - & + & - & - & + & - \\
\hline 8 & 姨 & Анаңның туған апай, сіңлілері & - & + & - & + & - & - & + \\
\hline 9 & 婶 & Әкеңнің туған інісінің әйелі & - & + & - & - & + & - & + \\
\hline 10 & 舅 & Анаңның туған аға, інілері & + & - & - & + & - & - & + \\
\hline 11 & 兄 & Аға, бір буын & + & - & + & - & - & + & - \\
\hline 12 & 弟 & Іні, ініңмен құрдас ер адам & + & - & + & - & - & + & - \\
\hline 13 & 姐 & $\begin{array}{c}\text { Апай, апайыңмен құрдас әйел } \\
\text { адам }\end{array}$ & - & + & + & - & - & - & + \\
\hline 14 & 妹 & Қарындас, сіңлі & - & + & + & - & - & - & + \\
\hline 15 & 夫 & Әйел адамның жұбайы & + & - & - & - & + & - & + \\
\hline 16 & 妻 & Ер адамның жұбайы & - & + & - & - & + & - & + \\
\hline 17 & 嫂 & Ағаңның әйелі & - & + & - & - & + & - & + \\
\hline 18 & 媳 & Ұлыңның жұбайы & - & + & - & - & + & - & + \\
\hline 19 & 女 & Қызың, кіші буын & - & + & + & - & - & - & + \\
\hline 20 & 子 & Ұлың, кіші буын & + & - & + & - & - & + & - \\
\hline 21 & 婿 & $\begin{array}{l}\text { Қызың, қарындасың, кіші } \\
\text { буын әйелдердің күйеулері }\end{array}$ & + & - & - & - & + & - & + \\
\hline 22 & 侄 & Аға, інілеріңнің ұлы & + & - & + & - & - & + & - \\
\hline 23 & 甥 & Апай, қарындастарыңның ұлы & + & - & + & - & - & - & - \\
\hline 24 & 孙 & Ұлыңның ұлы & + & - & + & - & - & + & - \\
\hline
\end{tabular}

Айшықтау тәсілі арқылы жасалған туыстық атаулар

Қытай тіліндегі айшықтау тәсілі арқылы жасалған туыстық атаулардың көбі ұрпақ дәрежесін, туыстықтың тура не жанама түрі екенін айқындау үшін қолданылады. Қытай тіліндегі айшықтау тәсілінің бөлшектері жеке дара сөз болып қолданылмайды. Олар тек негізгі түбір мор- фемаға жалғанып, оның мағынасын айшықтай түседі. Мұндай айшықтау сөздердің саны, 冯 汉瀷мырза 10 деп көрсетсе, кейіннен 阮氏翠幸 докторлық диссертациясында жаңа“亲”сөзін қосып, барлығы 11 айшықтау сөз болады (阮氏翠 幸. 2016: 52). Бұл пікірмен көптеген ғалымдар келіседі. Сол себептен де, төмендегі 2-кестеде осы 11 сөзге түсіндірме береді. 
Мухамедсадыкова А.Ж.

2-кесте. Қытай тілінің туыстық атаулардың айшықтау тәсілі арқылы жасалуы

\begin{tabular}{|c|c|c|c|c|}
\hline & Айшықтау & $\begin{array}{c}\text { Жеке } \\
\text { қолданылуы }\end{array}$ & Түсіндірмесі & Мысалы \\
\hline 1 & 高 & - & Жоғарғы төртінші ұрпақты білдіретін сөз & 高祖父、高祖母等 \\
\hline 2 & 曾 & - & Жоғарғы және төменгі үшінші ұрпақты білдіретін сөз & 曾祖父、曾孙等 \\
\hline 3 & 玄 & - & Төменгі төртінші ұрпақты білдіретін сөз & 玄孙、玄孙女等 \\
\hline 4 & 亲 & - & $\begin{array}{c}\text { Бір әке-шешеден туған немесе әртүрлі әке-шешеден туылған } \\
\text { болса да, олардың жұбайларымен тура қандас туыстықты } \\
\text { көрсету мақсатында қолданылатын сөз }\end{array}$ & $\begin{array}{l}\text { 亲爸、亲妈、亲兄、亲 } \\
\text { 姐妹、亲伯母、亲嫂 } \\
\text { 子、亲婶子等 }\end{array}$ \\
\hline 5 & 堂 & - & Екінші жанама туыстықты білдіретін сөз & 堂叔、堂兄等 \\
\hline 6 & 表 & - & $\begin{array}{c}\text { Әке-шешенің апайы мен қарындас, сіңлілерінің балалары } \\
\text { арасындағы қатынасты білдіретін сөз }\end{array}$ & $\begin{array}{l}\text { 表姑母、表姨夫、表 } \\
\text { 哥、表姐、表妹、表 } \\
\text { 弟等 }\end{array}$ \\
\hline 7 & 族 & - & $\begin{array}{c}\text { Төртінші дәрежелі жанама туыстықпен өте алыс туыстық } \\
\text { қатынасты білдіретін сөз }\end{array}$ & 族姐、族孙族侄等 \\
\hline 8 & 内 & - & $\begin{array}{c}\text { Әйеліңнің аға-інілері және кейінгі ұрпақтың бала-шағасын } \\
\text { білдіретін сөз }\end{array}$ & 内兄、内子等 \\
\hline 9 & 外 & - & $\begin{array}{c}\text { Анаңның әке-шешесі мен қызыңның бала-шағасын } \\
\text { білдіретін сөз }\end{array}$ & 外祖父、外孙女等 \\
\hline 10 & 从 & - & $\begin{array}{c}\text { “堂”сөзімен сәйкес қолданылады. “堂”сөзі кейіннен } \\
\text { қолданысқа енгізілген. Алайда “从”сөзінің қолданылу аясы } \\
\text { шектеулі. Екі сөзді бір-бірінің орнына алмастырып қолданы- } \\
\text { луға болады }\end{array}$ & 从叔、从兄、从弟等 \\
\hline 11 & 再从 & - & Үшінші жанама туыстықты білдіретін сөз & $\begin{array}{c}\text { 再从伯父、再从叔父、 } \\
\text { 再从姑母托 }\end{array}$ \\
\hline
\end{tabular}

Қайталама тәсілі арқылы жасалған туыстық атаулар

Қытай тіліндегі туыстық атаулар жүйесінде қайталама тәсілі өте кең таралған. Мысалы: “爷爷”、“奶奶”、“姥姥”、“爸爸”、“妈妈”、“ 姑姑”、“叔叔”、“哥哥”、“姐姐”、“弟弟”жəне т.б. Қытай тіліндегі қайталама тәсілі басқа тілдердегі қайталама тәсілдермен ұқсамайды. Сонымен қатар, қытай тіліндегі қайталама тәсілінің бір келкі грамматикалық мағынасы жоқ болғанымен, эмоционалдық тұрғыдан беретін әсері мол. Туыстық атаулар жүйесінде осы тәсілді қолданылуының 6 түрлі факторы бар. Олар: ұрпақтардың дәрежесі, жас ерекшелігі, туыстықтың тікелей не жанамалығы, туыстың жұбайының жынысы, тікелей емес туыстың ер не әйел екені және басқа да ерекше жағдайлардың болуы (冯汉瀷. 1989). Осы факторларға сүйене отырып, қайталама тәсілін үш топқа бөлуге болады.

Біріншісі, тек қана қайталану арқылы жасалатын, мысалы: “爷爷”、“奶奶”、“姥姥” 、“公公”、“婆婆”、“伯伯”және т.б.
Екіншісі, қайталанбайтын түрі, мысалы: “ 伯母”、“姑父”、“姨夫”、“姨妈”、“儿子”、“女 儿”、“侄子”、“侄女”、“孙子”、“孙女”、“外 孙”、“外甥”және т.б.

Үшіншісі, қайталанып та, жеке тұрыпта келетін, мысалы: “爸爸”、“妈妈”、“叔叔”、“婶 婶”、“姑姑”、“舅舅”、“哥哥”、“姐姐”、“妹 妹”、“弟弟”және т.б.

Қытай тілінің қайталама тәсілін қазақ тіліне қосарлама тәсілі деп аударып жүр. Алайда толығырақ зерттеп қарасақ, екеуі бір-бірімен сәйкестендіруге келмейді. Себебі қытай тілінің қайталама тәсілі осы тілдің ерекшелігі болып табылады.

\section{Қосымшалар жалғау тәсілі}

Қытай тіліндегі туыстық атаулардың қосымшалар жалғану арқылы жасалған түрлеpi, негізгі түбір морфемаға префикс, суффикс, қосымша жалғау арқылы жасалады. Туыстық атаулар осы тәсілдің екі түрімен жасалады. Біріншісі: Префикс+Түбір; Екіншісі: Түбір+Суффикс жалғану ( 阮氏翠幸. 2016: 50). 
1) Префикс+Түбір. Қытай халқы негізінен өте қарапайым әрі тұйық мінезді болып келеді. Күнделікті өмірде қарым-қатынас жасау барысында міндетті түрде сыпайлық, құрметтеу формаларын жиі пайдаланады. Туыстық атауларын пайдалану барысында да, сөй- леуші өзіне қатысты атауларды кішірейтіп, тыңдаушыға қатысты туыстық атауларды үлкен құрметпен, сыйластықпен атайды. Бұған үлкен септігін қосымшалар тигізеді. Мысалы, құрметтеу формасында Кесте 3 көрсетіген префикстер жалғанады.

3-кесте - Құрметтеу мақсатында қолданылатын префикстер

\begin{tabular}{|c|c|c|c|c|}
\hline & Қосымша & Түсіндірме & Қолданылу аясы & Мысалы \\
\hline 1 & 令 & Ардақты & Кез-келген қаратпа сөздің алдында & 令尊、令爱、令兄等 \\
\hline 2 & 尊 & Құрметті & $\begin{array}{c}\text { Тыңдаушының дәрежесі үлкен, аға буын } \\
\text { адамдарды туыстарын атау кезінде }\end{array}$ & 尊翁、尊兄等 \\
\hline \multirow{2}{*}{3} & 贤 & $\begin{array}{c}\text { Aca өнегелі, мәрте- } \\
\text { белі }\end{array}$ & $\begin{array}{c}\text { Тыңдаушының туысының аға буын болған } \\
\text { жағдайды }\end{array}$ & 贤叔、贤兄等 \\
\cline { 3 - 5 } & & \multirow{2}{*}{$\begin{array}{c}\text { Тыңдаушының туысының кіші буын болған } \\
\text { жағдайда }\end{array}$} & 贤弟、贤妹、贤孙等 \\
\hline
\end{tabular}

Кестеде келтірілген “令、尊、贤”сөздерінің қолданылу аясы әр түрлі, алайда бұл сөздердің қолданысында құрметтеу мағысы бәріне ортақ.

4-кесте - Кішіпейілділік көрсету мақсатында қолданылатын префикстер

\begin{tabular}{|c|c|c|c|c|}
\hline & Қосымша & Түсіндірме & Қолданылу аясы & Мысалы \\
\hline 1 & 家 & & Сөйлеуші өзінен жасы үлкен туысын атаған кезде & $\begin{array}{c}\text { 家父、家母、家兄、家 } \\
\text { 弟等 }\end{array}$ \\
\hline 2 & 舍 & & Сөйлеуші өзінен жасы кіші туысын атаған кезде & $\begin{array}{c}\text { 舍弟、舍孙、舍侄、舍 } \\
\text { 特等 }\end{array}$ \\
\hline 3 & 老 & & $\begin{array}{c}\text { Өзінің әке-шешесімен жасты туыстарын немесе өзі- } \\
\text { мен замандас адамдарды атаған кезде }\end{array}$ & $\begin{array}{c}\text { 老妈、老爸、老哥、老 } \\
\text { 弟等 }\end{array}$ \\
\hline 4 & 小 & Кішірею & $\begin{array}{c}\text { Өзіңнің кіші буын туыстарын, соның ішінде туған } \\
\text { балаларың мен немерелерін атаған кезде }\end{array}$ & $\begin{array}{c}\text { 小女、小儿、小弟、小 } \\
\text { 妹、小侄等 }\end{array}$ \\
\hline
\end{tabular}

Жоғарғы кестедегі “舍”префиксі көп жағдайларда бірінші дәрежелі жанама туыстықты атаған уақытта қолданылып, тікелей туыстықты атауда қолданылмайды. Сонымен қатар, “舍” префиксі “小” префиксімен алмастырып қолданыла береді. Ал “老”префиксіне келер болсақ, бұл префикс қытай тілінде өте ерекше, кең тараған префикстің бірі болып саналады. Бұл префикс жоғарғы ұрпақ және кіші буын туыстарын атауда қолданылмай, тек әке-шешеңмен замандас туыстардың арасын сөйлеу барысында жақындата түсу мақсатында кең қолданылады. Мысалы: “老姨、老舅” және т.б.

5-кесте - Сөйлеуші адам өзін атаған кезде қолданылатын префикстер

\begin{tabular}{|c|c|c|c|c|}
\hline & Қосымша & Түсіндірме & Қолданылу аясы & Мысалы \\
\hline 1 & 愚 & Ақымақ & Өз өзін атаған кезде & 愚兄、愚弟等 \\
\hline 2 & 小 & Қарапайым & Өз өзін атаған кезде & 小弟、小妹等 \\
\hline
\end{tabular}


2) Түбір+Суффикс. Бұл түрде жасалған туыстық атаулар қытай тілінде өте көп, әрі бұл форма кеңінен тараған. Мысал ретінде жиі жалғанатын “子”"суффиксінің өзі көптеген туыстық атаулардың жасалуына себепші. Мысалы: “ 嫂子”、“妻子”、“孩子”、“儿子”、“孙子” және т.б.

Қазақ тілінің туыстық атау терминдерінің сөзжасам ерекшелігі

Қазіргі заман қазақ тілінің сөзжасам жүйесі ұзақ уақыт дамудың нәтижесінде қалыптасқан. Тіліміздің сөзжасам жүйесінің негізі көне түркі тілдерінен бастау алып, содан бірі дамып, толығып, күрделеніп, сұрыпталып, екшелене келіп, қазіргі жүйелі дәрежеге жеткен (Салқынбай А. 2003).

Қай тілде болмасын сөзжасам ертеден келе жатқан тілдік құбылысқа жатады. Түркі тілдерінің ең көне жазба ескерткіштерінің тілі бұл мәселеге толық куә бола алады. Көне жазба ескерткіштер тілінде негізгі түбір сөздермен қатар туынды сөздер болғаны белгілі. Егер осы жазба ескерткіштерге толығырақ тоқталсақ, көне түркі тілінде сөзжасамның синтетикалық, аналитикалық және семантикалық тәсілдері болғанына көзіміз жетеді. Алайда нақты туыстық атау терминдерге тоқтарлар болсақ, қазақ тілінің туыстық атаулары синтетикалық және аналитикалық тәсілдер арқылы жасалады (Қазіргі қазақ тілінің сөзжасам жүйесі. 1989). Аталған тәсілдерге тоқталмас бұрын, қазақ тіліндегі негізгі түбір туыстық атауларды атап кетуді жөн көріп отырмыз.

\section{Негізгі түбір туыстық атаулар}

Қазақ тілінде негізгі түбір туыстық атауды білдіретін 30 сөз бар. Бұл сөздерді автор 2008 жылы жарық көрген 《Қазақ тілінің түсіндірме сөздігінен》 теріп алған. Мысалы: Баба, ата, әке, аға, іні, бауыр, ұл, құда, бай, бажа, әже, еже, шеше, ана, мама, ене, апа, сіңлі, тәте, әйел, қыз, баба, ата, әже, еже, әке, аға, іні, бауыр, апа, сіңлі, қыз, бала, ұл, немере, немене, темене. Ішіндегі 10 сөз ер жынысын (Баба 曾祖父, ата祖父, әке 父亲, аға兄长, іні弟弟, бауыр弟弟, ұл儿子, құда 亲家公, бай丈夫, бажа“连襟”关系的姐、妹夫), 11 сөз әйел жынысын (еже曾祖母, әже祖母, апа 外祖母, шеше母亲, ана母亲, мама母亲, ене婆婆, тәте姨妈, әйел妻子, сіңлі妹妹, қыз女儿) және 9 сөз ортақ (жар伴侣, жұп夫妻, бала孩子, нағашы 外亲, бөле表兄弟姊妹, жиен外孙, немере孙子, немене远孙, темене远孙) қолданыста.

Синтетикалық тәсіл арқылы жасалған туыстық атау терминдері
Туыстық атаулар негізінен зат есімдер қатарына жатады. Яғни жасалуы да зат есімдердің сөзжасамынен сәйкес келеді. Ал зат есім - сөзжасамы өте күрделі сөз табы. Зат есім сөзжасамдық жұрнақтарға өте бай, олардың мағынасы мен құрамында да үлкен ерекшелік бар. Зат есімнің синтетикалық тәсіл арқылы жасалуына сөзжасамдық жұрнақтар арқылы жасалуы жатады. Қазақ тілінің туыстық атаулары төмендегідей жұрнақтар жалғану арқылы жасалады.

Түбір сөзге -й жұрнағын жалғау арқылы жастар үлкендермен қарым-қатынаста халық дәстүріне сай этиканы сақтап, сыпайы сөйлеу мәнерін таныта алады (Диуанова.Р. 2010: 99). Мысалы: атай (祖父), бабай (曾祖父), әжей（祖母）, әкей（父亲）, шешей（母亲）, ағай（伯伯）, апай（姑姑）, жездей（姐夫）, жеңгей（嫂子）, тәтей（姨妈）.Сонымен қатар, -й жұрнағын жалғап, айтылған туыстық атаулар жақсы көріп сағыну, қадірлеп құрмет тұту, өтініп жалбарыну, жақын тартып еркелеп, мәпелеу үстемеленеді.

-жан, -тай, -ш, -еке аффиксті сөздердің мағынасы өзгерте, бояуын қоюлата, эмоциональды-экспрессивтік мәнін қосарлауға негізделген қолданыс. Мысалы: Атажан, Апажан, Әкежан, Ағажан, Анажан, Еркежан, Келінжан, көкежан, құдажан, тәтежан, ағатай, әжетай, енетай, әкетай, жеңгетай, шешетай, енеке, атеке, ағеке және т.б.

-шар аффиксі туыстық атаулардың шешесі жағынан төменгі үшінші ұрпақты атау мақсатында көп кездеседі. Мысалы: жиеншар, дегеншар, көгеншар, көбеншар, туашар.

- лас, -лес, -дас, -дес, -тас, -тес аффикстері көбіне туыс бірлігін білдіретін туынды сөз жасайды. Мысалы: ағайындас, аналас, шешелес, әкелес, бауырлас, елдес, жатырлас, жұбайлас, қандас, рулас, немерелес, сүйектес, шөберелес, төркіндес, туыстас және т.б.

-қай, -ғай//-ғый, -ғи жалпы түркілік зат есімдер тудыратын жұрнақтар. Мысалы: құдағай, құдағи сөздерін жатқызсақ болады.

-ша, -ше жұрнақтары туынды сөзді кішірейту, еркелету мақсатында қолданылады. Мысалы: әпше, жеңеше, құдаша және т.б.

-ын, -ін жұрнақтары тарихи формант болып табылады. Бұл тұлға қазіргі көптеген түркі тілдерінде негіздің ажырамас бөлігі ретінде қабылданады. Мысалы: абысын, қайын, қатын, төркін және т.б.

-дық, -тық, -тік, -лық жұрнақтары туыстықтың алыс не жақын дәрежесін айқындап көрсе- 
теді. Мысалы: жақындық, қандастық, руластық, туыстық, ағалық, тамырластық және т.б.

С. Бизақовтың айтуы бойынша, қазақ тілінің туыстық атаулардың қосымша жалғану арқылы сөз тудыру тәсілдері туралы тоқтала отырып, бұл сөздердің сыр-сипатын толық ашу тілдің грамматикалық, лексикалық құрылымын, дыбыстық жүйесін халқымыздың дүние танымымен, салт-санасымен, психологиялық тәрбиелік ерекшеліктерімен тығыз байланыстырады (Бизақов.С. 1990: 12-17).

\section{3. Аналитикалық тәсіл арқылы жасалған туыстық атау терминдері}

Қазақ тілінің сөзжасау тәсілінің кең қолданылатын бір түрі - аналитикалық тәсіл. Аналитикалық тәсіл - түбір сөздердің бірігуі, қосарлануы, тіркесуі, қысқаруы арқылы жаңа сөз тудыру тәсілі. Бұл тәсіл арқылы жасалған сөздер негізінен күрделі сөз болып табылады. Қазақ тілінің туыстық атаулары, жоғарыда айтылып кеткендей бірігіп, қосарланып және тіркесіп жасалады (http://kzref.org/azirgi-aza-tilini-morfologiyasi. html).

Сөз тіркестері. Сөз тіркесі деп толық мағыналы екі я бірнеше сөздің бір-біріне тұлғалық әрі мағыналық жағынан бағына байланысуын айтамыз. Қазақ тіліндегі тіркесіп жасалған туыстық атауларды бірнеше топқа бөліп қарастырдық.

1. Жоғарғы ұрпақты көрсету мақсатында "Үлкен”, “Арғы”, “Ұлы” сөздерімен тіркесу арқылы пайда болған сөздерді атап кетсек болады. Олар: Арғы ата（高祖父）, ұлы ата（祖 父), ұлы баба（祖父）, ұлы әже（祖母）, Үлкен ата（曾祖父）, үлкен әже（曾祖母）, үлкен апа（曾祖母） және т.б.

2. Қазақ тілінде қытай тілі сияқты шешесі жағынан туыстарды айқындау мақсатында “Нағашы”, яғни “外”сөзі жалғанып тіркес сөздерді тудырады. Мысалы: нағашы ата (外祖 父）, нағашы әже（外祖母）, нағашы апа（外祖 母), нағашы аға (大舅), нағашы іні (小舅), нағашы қарындас (表妹), нағашы жұрт (外 亲）, нағашы шеше（外祖母）және т.б.

3. Қазақ тілінде баланың нағашы жұртымен туыстық қарым-қатынасын білдіретін, сонымен қатар, қыздан туған баланы қыздын төркіні және рулас адамдары, яғни нағашылары “Жиен” деп атайды. Осы сөзбен тіркесіп те, қазақ тілінде бірталай туыстық атаулар пайда болды. Мысалы: жиен аға（姨表哥）, жиен апа（姨表姐）, жиен әпке (姨表姐), жиен бала（外甥）， жиен қарындас（姨表妹）, жиен қыз（外孙女）, жиен немере（外孙）, жиен іні（姨表弟）。
4. Сонымен қатар, қазақ тілінде "Қайын” сөзі, неке туыстығын білдіретін жалпылама термині, яғни ер немесе әйел адамға қатысты туыстық идеясын береді. Ер немесе әйелдің туысқандарын атау үшін қайын сөзі нақты мағынаға ие туыстық терминдерімен тіркеседі. Мысалы: қайын ата（公公或者岳父）, қайын аға（大伯父）, қайын апа (婆婆或岳母), қайын іні（小舅子或 小叔子），қайын сіңлі（小姨子或者小姑子）， қайын бике（大姑姐）, қайын жұрт（男方或女 方亲属的总称）.

5. Дүниеге шыр етіп келгеннен-ақ сақалды қария, ақ жаулықты әже болғанша қазақ халқы салт-дәстүр мен ырым-тиымдар арқылы қалыптасамыз. Осы салт-дәстүрлер көптеген туыстық атаулардың пайда болуына да себепкер болды. Қазақ халқының “Кіндік” сөзімен бір шама туыстық атаулар тығыз байланысты. Мысалы, кіндік шеше - әйел босанғанда көмек көрсетіп, нәрестенің кіндігін кесетін әйел. Қазақ салтындағы үлкен бір сыйлы ана, мол кәделі әйел «кіндік шеше» деп атайды. Кіндік шеше баланың екінші анасы болып саналады. Қазақ тілінің «кіндік шеше» сөзі, қытайдың “干妈” сөзімен сәйкес келеді. Осы «Кіндік» сөзімен тіркесу нәтижесінде, кіндік шеше (干妈), кіндік ата ( 干爷), кіндік әке (干爸), кіндік бала (干儿 子) пайда болды.

6. Некелік туыстық атауларға келер болсақ, қазақ салт-дәстүріне байланысты, "Бас құда", "Бел құда" және "Бесік құда" деген сөз тіркестеpi бар. Әрбір туыстық атауға түсіндірме берудің қажеті жоқ.

Біріккен сөздер. Сөздерді біріктіріп айту туыстық атаудың құрамында жиі кездесетін амал. Қазақ тіліндегі біріккен сөздерді алғаш зерттеген Ж.Досқараев тілдің бұл құбылысының туу, құралу тәсілі біркелкі емес, әр түрлі екендігін айтады. (Досқараев Ж. 1965: 193-200).

Біріккен сөздердің өзі екі түрлі болады. Кіріккен сөз және біріккен сөз. Қазақ тілінің туыстық атаулары осы екі түрмен жасалған түрлері бар.

Кіріккен сөз дегеніміз - сыңарлары дыбыстық өзгеріске түсіп, біртұтас лексикалық мағына беретін сөздер. Мысалы: Мырза+аға=Мырзаға ( 大伯子）、Мырза+қыз=Мырзағыз（小

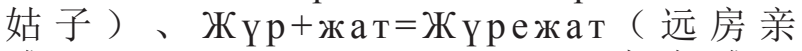
戚)、 Туу⿰жат $=$ Туажат（远房亲戚） 、Аға + іні=Ағайын (兄+弟=兄弟)、Қайын+ аға=Қайнаға（大伯子的另一种称呼）және т.б.

Біріккен сөз -сыңарлары дыбыстық құрамын сақтай отырып, бір мағынаға ие болатын сөздер. Мысалы: Кет+құда=Кетқұда, Бел+немеpe=Белнемере, От+аға=Отаға және т.б 
Қос сөздер. Қос сөз дегеніміз - қосарлану немесе қайталану арқылы бір ұғым ретінде жасалған сөздер. Жасалу тәсіліне қарай қос сөздер қайталама және қосарлама болып бөлінеді. Қайтамала қос сөз бір сөздің қайталанып айтылуынан жасалады. Қосарлама қос сөз өзара мәндес немесе қайшы мәндес сөздердің қосарлануынан жасалады. Қазақ тілінің туыстық атаулары сөзжасамында қосарлану арқылы жасалған түрлері кездеседі.

Қазақ тілінің қосарлама тәсілі арқылы жасалған туыстық атаулар үш түрлі лексикалық мағына береді.

1) Жалпылық мағынаны білдіретін туыстық атаулар: Ата-ана (父母), абысын-ажын（妯 娌), аға-жеңге (兄嫂), ағалы-қарындасты ( 兄妹）, ағалы-інілі（兄弟）, аға-іні（兄弟）, аналы-балалы (母子), апалы-сіңілі（姐妹, 说话者为女), апалы-қарындас (姐妹, 说话 者为男), апалы-інілі (姐弟), ата-баба（祖 父与祖父之上的祖辈关系), ата-ене (公婆), аталы-балалы (祖孙), әкелі-балалы (父子), әке-баба（父亲与祖父之间的祖辈关系), әкекөке (伯伯和父亲), әке-шеше (父母), әпкелі-інілі (姐弟), бай-бәйбіше (夫妻), бәйбіше-тоқал (妻妾), ерлі-зайыпты (夫妻), ерлі-байлы（有夫之妇）, қатын-бала（妻儿）, нағашы-жиен (外孙), немере-шөбере (子 孙), шешелі-балалы (母子), іні-қарындас ( 弟弟妹妹）， Әке-жәке（叔叔和父亲）， әкеYке（叔叔和父亲），ұл-қыз（子女）және т.б. Яғни бұл қос сөздерің сыңарлары нақты туыстық қатынасты білдіреді.

2) Жинақтық мағынаны білдіретін туыстық атаулар. Бұл туыстық атаулар көбіне туыстығы алыстау, немесе көпшілік адамды біріктіру мақсатында қолданылатын туыстық атаулар. Мысалы: ағайын-туған, ағайын-жегжат, ағайынжұрағат, ағайын-жұрағат, ағайын-туғандық, ағайын-тума, ел-жұрт, жақын-жаран, жақын-жора, жақын-жуық, жақын-жұрағат, жат-жақын, жатжұрағат, жегжат-жұрағат, құда-жегжат, құдақұдағи, өрен-жаран, туған-туысқан, туысқантуған, туыс-тума, үрім-бұтақ.

3) Қомсыну, менсінбеу, кемсіту мағынасында қолданылатын туыстық атаулар: келін-кепшік, қатын-қалаш, туыс-шатыс және т.б.

\section{Қорытынды}

Қытай және қазақ тілдерінің туыстық атау терминдерің сөзжасам ерекшеліктеріне тоқталмас бұрын, осы екі тілдің ең бірінші ерекшелігі типологиялық классификациясын атап кету артық болмас. Қытай тілі түбірлі немесе даралаушы тілдер қатарына жатады. Бұл тілдер қосымшалар арқылы түрленбей, сөз таптары формалық жақтан ашық ажырамаған тілдер. Оларда бір буынды омонимдес сөздер жиі ұшырасып, бір-бірінен музыкалық екпін арқылы ажыратылады. Ал қазақ тілі болса, агглютинативті тілдер қатарына жатады. Яғни жұрнақтар мен жалғаулар кең таралған және түбірдің үстіне бірінен соң бірі үстемеленіп жалғана береді.

Қытай тілінің негізгі түбір сөзден жасалған 24 туыстық атау болсын, 10 қосымшалары болсын, барлығы бір буынды сөздерден құралған. Яғни екі немесе үш буыннан құралған туыстық атауды кездестірмейміз. Қазақ тілінде бұндай ерекшелік байқалмайды.

Жыныстық категориялық бөлініс бір келкі емес. Қытай тіліндегі 24 негізгі түбір сөзден жасалған туыстық атаулардың 13-і ер жынысты, 10 әйел жынысты және 1 сөз ортақ қолданылса, қазақ тіліндегі 30 негізгі түбір сөздің 10-ы ep, 11 әйел және 9 ортақ қолданыста. Осы ортақ қолданыстаға сөздердің көбі кіші буын ұрпақтарды атау сөздері. Бұған негізгі себеп, қазақ халқы ұрпақты атау кезінде, жынысына аса қатты мән бермеген. Нәрестенің ұл не қыз жынысты болғаны емес, ұрпақ көбейгені маңыздырақ болғанын дәлелдейді. Алайда қытай халқының идеологиясында ұл баланы қыз балаға қарағанда артығырақ сүйгені бәрімізге мәлім.

Қытай тіліндегі туыстық атаулар "Префикс+Түбір" және “Түбір+Суффикс" формалары арқылы жасалса, қазақ тілі тек "Түбір+Суффикс" формасымен жасалады. Аталған ерекшеліктерге қарамастан, қытай және қазақ тілінің туыстық атауларының сөзжасамының ұқсастықтары бар.

Қытай және қазақ тілдерінің туыстық атау терминдерінің сөзжасамы өте күрделі әрі сан алуан түрлі. Аталған тілдердің негізгі түбір сөз туыстық атаулары бірнеше бірдей категорияға бөлінеді. Мысалы: жынысы, туыстық қатынастың әкелік, шешелік немесе некелік екендігіне көңіл бөлініп қана қоймай, ұрпақ дәрежесіне де аса мән беріледі. Қытай тіліндегi “父、伯、叔、舅、兄、母、故、姨、姐、 妹”сөздері қазақ тілінің “Баба, әке, аға, іні, әже, еже, шеше, ана, мама, апа, сіңлі"сияқты сөздерде жыныстық категория ажыратылған.

Қытай-қазақ тілдерінің туыстық атауларына сипаттамалық қасиет тән. Яғни туыстың қатысын білдіру мақсатында міндетті түрде айқындайтын сөздерді қосып айтады. Бұл осы халықтардың 
туыстық қатынасының күрделі жүйесіне тікелей байланысты.

Сонымен қатар, аталған тілдер “Анықтауыш + Негізгі сөз” формасымен ұстанады. Мысалы, қытай тіліндегі “堂哥、堂弟、表姐、表妹、 外孙、外孙女、外甥”сөздеріндегі “堂、表、 外”сөздері, “哥、弟、姐、妹、甥”сөздерінің анықтауышы болып табылады. Қазақ тіліндегі “Нағашы аға, нағашы ата, нағашы әже, ұлы ата, ұлы әже, үлкен ата, арғы, кенже бала"сөздеріндегі “Нағашы, ұлы, үлкен, арғы, кенже”сөздеріде тұра сондай.
Қазақ және қытай тілдерінің күрделі туыстық атау терминдеріне қарасақ, жоғарғы дәрежелі ұрпақты білдіретін сөз, кейінгі ұрпақты білдіретін сөздің алдында келеді.

Мысалы, қытай тіліндегі “祖孙、娘儿、父 子、母子、婆媳、兄弟、姐妹”және т.б. Қазақ тіліндегі “аға-іні, аналы-балалы, апалы-сіңілі, апалы-інілі, аталы-балалы, нағашы-жиен”және т.б. сөздері дәлел бола алады. Бұл ерекшелікте екі халықтың үлкенге ізет, құрмет, сыйластық қарым-қатынасы тілде сипат алып отыр деуге болады.

\section{Әдебиеттер}

王火、王学元的《汉语称谓词典》(辽宁大学出版社, 1988年)

鲍海涛、王安节的《亲属称呼词典》(吉林教育出版社, 1988年)

陆瑛的《简明称谓辞典》(广西民族出版社, 1989年)

《现代汉语词典》第七版，（商务印书馆）2016年

冯汉骥, 《中国亲属称谓指南》，上海文艺出版社，1989

胡士云的《汉语亲属称谓研究》，商务印书馆， 2007

阮氏翠幸的博士论文《汉、越语亲属称谓语对比研究》，华中师范大学，2016

刘超班《论亲缘称谓的开放性》，武汉教育学院学报，1996年10月，第15卷 第5期

Қазақ тілінің түсіндірме сөздігі. -Алматы, 1974-1986 жж

Қазақ тілінің түсіндірме сөздігі. -Алматы, 2008жж

Сарыбаева М. Система обозначении родства в английском, русском и казахском языках. - Алма-Ата, 1991.

Жолдасбек Л. Қазақ сөйленістеріндегі туыстық атаулар», Алматы, 1998

Диуанова Р. «Қазақ тіліндегі туыстық атаулардың мағыналық құрылымы мен лексикографиялану ерекшеліктері», Алматы, 2010

Бизақов С. Қазақ тіліндегі туыстық атаулардың берілуі //Қазақ ССР ҒА Хабарлары, Филол.бөлімі. -3-шығ. -1990. -Б. 12-17

Оралбай Н. Қазақ тілінің сөзжасамы. -Алматы, 2002

Салқынбай А. Қазақ тілі сөзжасамы. -Алматы, 2003

Қазіргі қазақ тілінің сөзжасам жүйесі. Алматы, 1989

Тоқтарова Т. Сөзжасам мәселесінің зерттелуі // Қазақ тілі мен әдебиеті, 1994, №3.

Бейсембаева 3. Сөзжасамның зерттелу аспектісі // Қазақ тілі мен әдебиеті, № 9, 2003, 34-36-б.б

Досқараев Ж. Арыс говорының сөз тіркестері // Қазақ диалектологиясы. Мақалалар жинағы. -Алматы, 1965. -1-шығ. -193-200-б.

https://lektsii.org/6-9826.html

http://kzref.org/azirgi-aza-tilini-morfologiyasi.html

\section{References}

Wang Huo, Wang Xue Yuan . Chinese Appellation Dictionary, Liao Ning Universiry Press, 1988

Bao Hai Tao, Wang An Jie. Dictionary of Kinship Terminology, Ji lin Educational Press, 1988

Lu Ying. Concise apparition Dictionary, Guang Xi National Press, 1989

"Modern Chinese dictionary" seventh edition, (commercial press $\square, 2016$

Feng Han Ji. "The appellation of relatives in China", Shanghai literature and art publishing house, 1989

Hu Shi Yun. Study of Chinese Kinship Terminology, Commercial Press, 2007

Ruan Shi Cui Xing. Comparative study of Chinese and Vietnamese kinship terminology, Central China Normal University, 2016

Liu Chao Ban. The openness features of kinship terms, Journal of Wuhan Institute of Education, 1996

Qazaq tilining tusindirme sozdigi. - Almaty, 1974-1986

Qazaq tilining tusindirme sozdigi. - Almaty, 2008

Sarybaeva M. Sistema oboznachenii rodstva v angliiskom, russkom i kazakhskom yazykah, Alma-ata. 1991

Zholdasbek L. Qazaq soilenisterindegi tuystyk ataular, Almaty, 1998

Diuanova R. Qazaq tilindegi tuystyk ataulardyng magynalyq qurylymy men leksikografiyalanu erekshelikteri, Almaty, 2010

Bizaqov.S. Qazaq tilindegi tuystyk ataulardyn berilui//Qazaq SSR GA Khabarlary, Filol.bolimi -3. 1990

Oralbay N. Qazaq tilining sozzhasamy. - Almaty,2002

Salkynbay A. Qazaq tili sozzhasamy. - Almaty, 2003

Qazirgi qazaq tilining sozzhasam zhuesi. Almaty, 1989

Toktarova T. Sozzhasam maselesining zertteuleri//Qazaq tili men adebieti, 1994, №3.

Beisembayeva Z. Sozzhasamnyng zerttelu aspektisi // Qazaq tili men adebieti, № 9, 2003

Doskarayev Z. Arys govorynyng soz tirkesteri // Qazaq dialektologiyasy. Makalalar zhinagy. -Almaty, 1965. 